\title{
HUBUNGAN PENGETAHUAN DAN SIKAP TENTANG HIV-AIDS PADA REMAJA DI KABUPATEN BOYOLALI
}

\author{
Relationship Of Knowledge And Attitude Of Hiv-Aids In Adolescents In The \\ District Boyolali
}

\author{
Sri Iswahyuni ${ }^{1}$, Sri Sayekti Heni $\mathbf{S}^{2}$, Herbasuki ${ }^{3}$ \\ (iswahyunisri@yahoo.co.id)
}

\begin{abstract}
ABSTRAK
Latar Belakang : Jumlah pasien HIV/AIDS di dunia terus meningkakat. Di Indonesia termasuk di Kabupaten Boyolali jumlahnya juga terus meningkat. Di Kabupaten Boyolali penemuan kasus baru HIV/AIDS tahun 2015 sebanyak 72 kasus, mengalami peningkatan bila dibanding tahun 2014 sebanyak 43 kasus, dan proporsi penderita HIV/AIDS didominasi kaum laki-laki $65,75 \%$ perempuan $34,25 \%$. Bila dilihat dari golongan umur, sebagian besar penderita HIV/AIDS didominasi pada usia produktif 25-49 tahun. Tingkat pengetahuan dan kesadaran mengenai pencegahan HIV/AIDS di sinyalir sebagai salah satu faktor yang mempengaruhi tingginya peningkatan kasus penderita penyakit HIV/AIDS di masyarakat.

Tujuan : Mengetahui hubungan pengetahuan dan sikap tentang HIV/AIDS pada remaja di Kabupaten Boyolali, terutama di Desa Cabeankunti, Kecamatam Cempogo.

Metode : Penelitian ini dilaksanakan dengan pendekatan waktu cross sectional. Populasi penelitian ini adalah seluruh remaja (Remaja : orang-orang yang berumur 10-19 dan tidak kawin yang tinggal di Desa Cabeankunti, Cempogo, Boyolali sebanyak 201 orang. Sampel diambil dengan purposive sampling dimana jumlah sampel dapat dimaksimalkan yang bisa dijangkau untuk mewakili populasi secara maksimal. Sampel dalam penelitian ini sejumlah 141 responden. Analisis hubungan menggunakan uji korelasi Kendall's tau-b

Hasil : Pengetahuan tentang HIV/AID remaja cabeankunti, Cempogo, Boyolali adalah baik : 27 responden atau $19.15 \%$, cukup 90 responden atau $63.8 \%$ dan kurang 24 responden atau $17.02 \%$. Sikap remaja terhadap HIV/AIDS. adalah baik $25(17.73 \%)$ responden, cukup $77(54.61 \%)$ responden, kurang $34(27.66 \%)$ responden. Hasil analisis uji korelasi Kendall's tau-b ada hubungan yang bermakna antara pengetahuan dan sikap remaja terhadap HIV/AIDS dimana diperoleh nilai $\mathrm{p} 0.000$ dan $\mathrm{p}<0.05$. Nilai korelasi 0.558 menunjukkan korelasi positif dengan kekuatan korelasi sedang (antara $0.4-<0.6$ )
\end{abstract}

Simpulan : ada hubungan antara pengetahuan dan sikap remaja tentang HID/AIDS di Kabupaten Boyolali.

Kata Kunci : Pengetahuan, Sikap, Remaja, HIV/AIDS 


\begin{abstract}
Background Back : The total numbers of HIV/AIDS patients in the world increased. In Indonesia including in the Regency Boyolali the amount is too high increase. In Boyolali invention case of new HIV/AIDS in 2015 was 72 cases, experiencing enhancement when compared to 2014 there were only 43 cases, and proportion HIV/AIDS sufferers are dominated by male $65.75 \% 34.25 \%$ female. HIV/AIDS sufferers are dominated on age productive 25-49 years. Level of knowledge and attitude are about HIV/AIDS prevention is initiated as factor that affected the improvement case HIV/AIDS in the community

Purpose : to under staid of relationship knowledge and attitude about HIV-AIDS in teenagers in the Regency Boyolali, especially in approach Cabeankunti, Cempogo.
\end{abstract}

Method : The research was done with cross sectional approach. The Population research this is all over teenagers (adolescents : people aged 10-19 and not mate) who lives in the Village Cabeankunti, Cempogo, Boyolali as many as 201 people. Sample taken purposive sampling where total sample could maximized that could reachable for represent population in a manner maximum. Sample in research leader this 141 number of respondents. Tester is used for analyze the relationship between knowledge and attitude Kendall's tau-b correlation.

Results: Knowledge about HIV/AIDS adolescents cabeankunti, Cempogo, Boyolali is good : 27 respondents or $19.15 \%$, enough 90 respondents or $63.8 \%$ and less than 24 respondents or $17.02 \%$. Attitude teenager against HIV/AIDS is good $25(17.73 \%)$ respondents, only $77(54.61 \%)$ respondents, less $34(27.66 \%)$ respondents. Results test Kendall's tau-b analysis relationships were meaningful between knowledge and attitude teenager against HIV/AIDS where obtained $\mathrm{p}$ value of 0,000 and $p<0.05$. Value the correlation of 0.558 shows of the correlation positive with power correlation medium ( between $0.4-<0.6$ )

Conclusion : there is relationship between knowledge and attitude teenager about HIV/AIDS in the Boyolali .

Keywords: Knowledge, attitude, adolescence, HIV / AIDS.

\title{
PENDAHULUAN
}

Human Immunodeficiency Virus (HIV) merupakan virus yang dapat melemahkan kekebalan tubuh pada manusia sedangkan Acquired Immune Deficiency Syndrome (AIDS) merupakan kumpulan dari gejala dan infeksi atau biasa disebut sindrom yang diakibatkan oleh kerusakan sistem kekebalan tubuh manusia karena virus. Kementrian Kesehatan Republik Indonesia bekerja sama dengan Wordl Health Organization (WHO) melaksanakan kajian Nasional Respon Bidang Kesehatan terhadap HIV, pada tanggal 16-27 Januari 2017 yang melaporkan bahwa diperkirakan terdapat sekitar 630.000 Orang Dengan HIV AIDS (ODHA) di Indonesia pada tahun 2015. Prevalensi HIV pada tingkat nasional untuk kelompok usia 15 tahun keatas diperkirakan mencapai $0.3 \%$ pada tahun 2015 (WHO, 2017). 
Di Kabupaten Boyolali penemuan kasus baru HIV/AIDS tahun 2015 sebanyak 72 kasus, mengalami peningkatan bila dibanding tahun 2014 sebanyak 43 kasus. Pada tahun 2015 dilaporkan kasus baru HIV sebanyak 46, kasus baru AIDS sebanyak 26, dengan jumlah kematian karena AIDS sebanyak 12. Bila dilihat proporsi penderita HIV/AIDS didominasi kaum laki-laki $65,75 \%$ perempuan $34,25 \%$. Bila dilihat dari golongan umur, sebagian besar penderita baik HIV/AIDS didominasi pada usia produktif 25-49 tahun (Dinkes Kab. Boyolali, 2015).

Cara penularan : 1. Melalui darah misalnya : transfusi darah, terkena darah HIV positif pada kulit yang terluka, jarum suntik dan sebagainya. 2. Melalui cairan semen, air mani (sperma atau peju Pria). misalnya ; seorang pria berhubungan badan dengan pasangannya tanpa menggunakan kondom atau pengaman lainnya, oral sex dan sebagainya. 3. Melalui cairan vagina pada wanita. misalnya : wanita yang berhubungan badan tanpa pengaman, pinjam-meminjam alat bantu seks, oral seks dan sebagainya . 4. Melalui Air Susu Ibu (ASI), misalnya : bayi meminum ASI dari wanita HIV positif, pria meminum susu ASI pasangannya dan sebagainya.

Menurut Depkes (KPA Nasional, 2005) penyebaran HIV/AIDS dan pencegahannya dapat dilakukan dengan prinsip " $\mathrm{ABC}$ " yang telah efektif untuk menurunkan jumlah penularan HIV/AIDS Prinsip "ABC" itu adalah A : Anda jauhi seks sampai anda kawin atau menjalin hubungan jangka panjang dengan pasangan, B: Bersikap saling setia dengan pasangan dalam hubungan, C: Cegah dengan memakai kondom secara benar dan konsisten untuk penjaja seks atau orang yang tidak mampu melaksanakan A dan B (Kondom). Untuk penularan non-seksual, berlaku prinsip “ D dan E” yaitu: D: Drug: say no to atau katakan tidak pada napza/narkoba, E: Equipment: no sharing atau jangan memakai alat suntik secara bergantian.

Pengetahuan adalah sesuatu yang hadir dan terwujud dalam jiwa dan pikiran seseorang dikarenakan adanya reaksi, persentuhan, dan hubungan dengan lingkungan dan alam sekitarnya. Pengetahuan ini meliputi emosi, tradisi, keterampilan, informasi, akidah, dan pikiran-pikiran. Sikap adalah suatu proses evaluasi yang sifatnya internal/subjektif yang berlangsung dalam diri seseorang dan tidak dapat diamati secara langsung. Sikap dapat diketahui dari pengetahuan, keyakinan, perasaan dan kecenderungan tingkah laku seseorang terhadap suatu objek (Sarwono, 2011)

Tingkat pengetahuan dan kesadaran mengenai pencegahan HIV/AIDS merupakan salah satu faktor yang mempengaruhi tingginya peningkatan kasus penderita penyakit HIV/AIDS di masyarakat. Berdasarkan data-data diatas maka peneliti tertarik untuk meneliti Hubungan Pengetahuan dan Sikap tentang HIV/AIDS.

\section{METODE PENELITIAN}

Penelitian ini dilaksanakan dengan pendekatan waktu cross sectional. Populasi penelitian ini adalah seluruh remaja (Remaja : orang-orang yang berumur 10-19 dan tidak kawin yang tinggal di Desa Cabeankunti, Cempogo, 
Boyolali sebanyak 201 orang. Sampel diambil dengan non probability sampling purposive sampling dimana menurut peneliti jumlah sampel dapat dimaksimalkan untuk mewakili populasi. Sampel dalam penelitian ini adalah 141.

Alat pengumpulan data pada penelitian ini adalah kuessioner tentang pengetahuan dan sikap yang telah dilakukan uji validitas dan reliabilitas. Metode pengumpulan data untuk tingkat pengetahuan dan sikap tentang HIV/AIDS dalam penelitian ini adalah menggunakan data primer yang diperoleh dari pengisian kuesioner oleh responden yang diisi sesuai dengan petunjuk dan di kumpulkan kembali pada hari yang sama. Analisis yang akan digunakan dalam penelitian ini adalah analisis univariat dan analisis bivariat. Variabel yang dianalisis secara univariat dalam nilai presentasi variabel pengetahuan dan sikap. Analisis bivariat dilakukan terhadap dua variabel digunakan berhubungan atau berkorelasi. Untuk menghitung skor masing-masing pertanyaan menggunakan korelasi kendall's tau dengan menggunakan SPSS 17

\section{HASIL DAN PEMBAHASAN}

Tabel I Distribusi Frekwensi Karakteristik Responden Menurut Umur

\begin{tabular}{lcc}
\hline Umur & Frekwensi $(\mathbf{f})$ & Posentase $(\%)$ \\
\hline 10 Tahun & 0 & 0 \\
11 Tahun & 0 & 0 \\
12 Tahun & 5 & 3.5 \\
13 Tahun & 17 & 12.1 \\
14 Tahun & 20 & 14.2 \\
15 Tahun & 35 & 24.8 \\
16 Tahun & 23 & 16.3 \\
17 Tahun & 24 & 17.0 \\
18 Tahun & 10 & 7.1 \\
19 Tahun & 7 & 5.0 \\
\hline Total & $\mathbf{1 4 1}$ & $\mathbf{1 0 0 . 0}$ \\
\hline
\end{tabular}

Berdasarkan tabel diatas diketahui bahwa mayoritas responden adalah usia 15 tahun yaitu sebesar 24,8 \%. Dan tidak ada responden yang berusia 10 dan 11 tahun.

Tabel 2 Distribusi Frekwensi Karakteristik Responden Menurut Pendidikan

\begin{tabular}{llc}
\hline Pendidikan & Frekwensi & Prosentase (\%) \\
\hline SD & 10 & 7.1 \\
SMP & 73 & 51.8 \\
SMA/MA/SMK & 52 & 36.9 \\
PT & 6 & 4.3 \\
\hline Total & $\mathbf{1 4 1}$ & $\mathbf{1 0 0 . 0}$ \\
\hline
\end{tabular}

Berdasarkan tabel diatas mayoritas responden masih duduk di bangku pendidikan SMP yaitu sebesar 51.8\% dan hanya 6 responden (4.3\%) yang penempuh pendidikan ditingkat perguruan tinggi. 
Tabel 3 Distribusi Frekwensi Karakteristik Responden Menurut Jenis Kelamin

\begin{tabular}{llc}
\hline Jenis Kelamin & Frekwensi & Prosentase (\%) \\
\hline Laki-laki & 76 & 53.9 \\
Perempuan & 65 & 46.6 \\
\hline Total & $\mathbf{1 4 1}$ & $\mathbf{1 0 0 . 0}$ \\
\hline
\end{tabular}

Tabel 3 menunjukan $33.9 \%$ responden berjenis kelamin laki-laki dan $46.6 \%$ responden berjenis kelamin perempuan.

Tabel 4 Sumber Informasi tentang HIV/SIDS yang Peroleh Responden

\begin{tabular}{llc}
\hline Sumber Informasi & Frekwensi & Prosentase $\mathbf{( \% )}$ \\
\hline Radio & 1 & 0.96 \\
Televisi & 36 & 34.62 \\
Surat Kabar & 2 & 1.92 \\
Poster & 5 & 4.81 \\
Petugas kesehatan & 6 & 5.77 \\
Perkumpulan Agama & 7 & 6.73 \\
Sekolah & 17 & 16.35 \\
Perkumpulah Masyarakat & 4 & 3.85 \\
Teman/Keluarga & 4 & 3.85 \\
Tempat Kerja & 0 & 0.00 \\
Internet & 19 & 18.27 \\
Lainnya & 3 & 2.88 \\
\hline Jumlah & $\mathbf{1 0 4}$ & $\mathbf{1 0 0 . 0 0}$ \\
\hline
\end{tabular}

Tabel diatas menunjukkan bahawa informasi tentang HIV/AIDS paling banyak di peroleh dari televisi sebesar $34.62 \%$ dan disusul berikutnya adalah internet dan sekolah masing-masing $18.27 \%$ dan $16.35 \%$.

Tabel 5. Distribusi Frekuensi Variabel Pengetahuan tentang HIV/AID Remaja di Desa Cabeankunti, Cempogo, Boyolali.

\begin{tabular}{llc}
\hline Pengetahuan & Frekwensi & Prosentase (\%) \\
\hline Baik & 27 & 19.15 \\
Cukup & 90 & 63.83 \\
Kurang & 24 & 17.02 \\
\hline Total & $\mathbf{1 4 1}$ & $\mathbf{1 0 0}$ \\
\hline
\end{tabular}

Tabel 5 menunjukkan bahwa tingkat pengetahuan tentang HIV/AID remaja cabeankunti, Cempogo, Boyolali adalah cukup : 90 Orang atau 63.83. Pengetahuan baik 19.15 dan kurang $17.02 \%$. 
Tabel 6. Distribusi Frekuensi Variabel Sikap tentang HIV/AID Remaja di Desa Cabeankunti, Cempogo, Boyolali

\begin{tabular}{llc}
\cline { 2 - 3 } Sikap & Frekwensi & Prosentase (\%) \\
\hline Baik & 25 & 17.73 \\
Cukup & 77 & 54.61 \\
Kurang & 39 & 27.66 \\
\hline Total & $\mathbf{1 4 1}$ & $\mathbf{1 0 0}$ \\
\hline
\end{tabular}

Berdasarkan tabel diatas rata-rata sikap remaja Desa Cabeankunti, Cempogo Boyolali adalah cukup (54.61\%). Kurang 27.66 dan yang baik $17.73 \%$.

Tabel 7. Analisa Korelasi Gamma Pengetahuan dan Sikap tentang HIV/AID pada Remaja di Desa Cabeankunti, Cempogo, Boyolali

Pengetahuan dan Sikap Crosstabulation

\begin{tabular}{|c|c|c|c|c|c|c|}
\hline & & & \multicolumn{3}{|c|}{ Sikap } & Total \\
\hline & & & Baik & Cukup & Kurang & \\
\hline \multirow[t]{3}{*}{ Pengetahuan } & \multicolumn{2}{|l|}{ Baik } & 16 & 9 & 2 & 27 \\
\hline & \multicolumn{2}{|c|}{ Cukup } & 9 & 63 & 18 & 90 \\
\hline & \multicolumn{2}{|c|}{ Kurang } & 0 & 5 & 19 & 24 \\
\hline \multirow[t]{4}{*}{ Total } & & & 25 & 77 & 39 & 141 \\
\hline & \multicolumn{5}{|c|}{ Symmetric Measures } & \\
\hline & \multicolumn{5}{|c|}{ Asymp. Std. } & Approx. \\
\hline & \multicolumn{4}{|c|}{ Error $^{\mathrm{a}}$} & Approx. $\mathrm{T}^{\mathrm{b}}$ & Sig. \\
\hline $\begin{array}{l}\text { Ordinal by } \\
\text { Ordinal }\end{array}$ & $\begin{array}{l}\text { Kendall's } \\
\text { tau-b }\end{array}$ & .558 & \multicolumn{2}{|c|}{.063} & 7.335 & .000 \\
\hline $\begin{array}{l}\mathrm{N} \text { of Valid } \\
\text { Cases }\end{array}$ & \multicolumn{5}{|c|}{141} & \\
\hline
\end{tabular}

a. Not assuming the null hypothesis

b. Using the asymptotic standard error assuming the null hypothesis.

\begin{tabular}{lllllllcl}
\hline Pengetahuan & \multicolumn{9}{c}{ Sikap } & & & \begin{tabular}{c} 
Koefisien \\
Korelasi \\
\cline { 2 - 7 }
\end{tabular} & Baik & $\mathbf{( \% )}$ & Cukup & $\mathbf{( \% )}$ & $\begin{array}{c}\text { Ku } \\
\text { rang }\end{array}$ & Nilai p \\
\hline Baik & 16 & 11.35 & 9 & 6.38 & 2 & 1.42 & 0.558 & 0.000 \\
Cukup & 9 & 6.38 & 63 & 44.68 & 18 & 12.77 & & \\
Kurang & 0 & 0 & 5 & 3.55 & 19 & 13.48 & & \\
Total & 25 & 17.73 & 77 & 54.61 & 39 & 27.66 & & \\
\hline
\end{tabular}

Uji Korelasi Kendall's tau-b 
Dari tabel diatas diperoleh nilai p 0.000 yang menunjukkan bahwa korelasi antara pengetahuan dan sikap remaja terhadap HIV/AIDS adalah bermakna karena $\mathrm{p}<0.05$. Nilai korelasi 0.558 menunjukkan korelasi positif dengan kekuatan korelasi sedang (antara 0.4- <0.6).

Hasil penelitian Tabel 5 menunjukkan bahwa tingkat pengetahuan tentang HIV/AID remaja cabeankunti, Cempogo, Boyolali responden yang pengetahuannya baik ada 27 responden (19.15\%), cukup : 90 0rang atau $63.83 \%$. dan kurang 24 responden (17.02 \%). Faktor-faktor yang mempengaruhi pengetahuan ada faktor internal dan eksternal, faktor internal antara lain pendidikan, pekerjaan dan umur sedangkan yang termasuk kedalam factor eksternal adalah lingkungan dan sosial budaya (Wawan, 2011).

Tingkat pengetahuan remaja pada penelitian ini beragam, hal ini terjadi karena paparan informasi tentang HIV/AIDS juga beragam. Ada yang sama sekali belum memdapatkan informasi ada yang sudah bahkan ada yang mendapatkan sumber informasi lebih dari satu sumber. Sumber informasi yang diperoleh responden antara lain radio, televisi, surat kabar, poster, petugas kesehatan, perkumpulan agama, sekolah, perkumpulan masyarakat, teman/keluarga, tempat kerja, internet dan sumber lainya. Hasil penelitian ini menunjukkan bahwa pengetahuan HIV/AIDS respoden diperoleh dari televisi sebesar $34.62 \%$ dan disusul berikutnya adalah internet dan sekolah masing-masing $18.27 \%$ dan $16.35 \%$. Individu yang mempunyai sumber informasi yang lebih banyak akan mempunyai pengetahuan yang lebih banyak. Sumber informasi bepengaruh terhadap tinggi rendahnya pengetahuan responden tentang HIV/AIDS.

Responden mayoritas pelajar, pendidikan adalah upaya untuk memberikan pengetahuan, sehingga terjadi pemahaman perilaku positif yang meningkat. Semakin tinggi pendidikan seseorang, membuat seseorang menjadi lebih mudah menerima hal-hal baru, sependapat dengan Wawan (2011), Notoatmodjo (2010) juga mengatakan salah satu faktor yang mempengaruhi pengetahuan adalah pendidikan. Responden rata-rata adalah pelajar/masih sekolah dan $16.5 \%$ responden mengatakan bahwa ia memperoleh informasi tentang HIV/AIDS dari sekolah.

Umur responden bervariasi. tabel 4 menunjukkan bahwa mayoritas responden adalah usia 15 tahun yaitu sebesar 24,8 \%. Usia Responden terbanyak berikutnya adalah usia 17 tahun sebanyak 24 responden (17.0) dan 16 tahun sebanyak 23 orang $(16.3 \%)$ menurut Wawan (2011) masyarakat pada umumnya menilai bahwa seseorang yang lebih dewasa akan lebih dipercaya dibandingkan orang yang belum tinggi kedewasaannya. Hal ini berkaitan dengan pengalaman dan kematangan jiwa seseorang tersebut. Semakin cukup umur, seseorang akan semakin lebih matang dalam berfikir dan bekerja. Pada penelitian ini meskipun usia responden masih muda yaitu 12-19 tahun (usia remaja) pengetahuanya tentang HIV rata-rata cukup dan baik, yang kurang hanya $17.02 \%$ karena mereka cukup mendapat informasi .

Pengetahuan sangat berkaitan dengan sikap, terdapat hubungan antara pengetahuan dan sikap. Semakin baik pengetahuan responden tentang HIV/AIDS maka sikapnya terhadap HIV/AIDS juga semakin baik, dan sebaliknya responden yang pengetatahuannya tentang HIV/AIDS kurang maka sikapnya terhadap 
HIV/AIDS juga kurang. Pengetahuan tentang HIV/AIDS mulai dari pengertian, tanda gejala, cara penularan dan cara pencegahan dan lain-lain akan membentuk sikap, kemudian dari sikap itu akan menentukan apakah kegiatan yang akan dilakukan untuk menghindari penularan, pencegahan dan memperlakukan pasien HIV/AIDS dengan tepat. Sehingga semakin baik pengetahuan mengenai HIV/AIDS maka semakin baik sikapnya terhadap HIV/AIDS. Jadi pengetahuan sangat mempengaruhi sikap seseorang untuk melakukan suatu tindakan, hal ini memberikan landasan kognitif bagi terbentuknya sikap, dalam penelitian ini sikap yang baik di landasi pengetahuan yang baik. Hasil penelitian ini sejalan dengan penelitian Lia : Hubungan Pengetahuan Suami Tentang HIV/AIDS dengan Pencegahan Berdasarkan Karakteristik di Desa Parakan Kauman Kecamatan Parakan Kabupaten Temanggung

Sikap juga dipengaruhi faktor-faktor lain seperti budaya, nilai-nilai, keyakinan, aturan dan norma. Sikap menurut Wawan (2011) dipengaruhi faktor pengalaman pribadi, pengaruh orang lain yang dianggap penting, pengaruh kebudayaan, media massa, lembaga pendidikan dan lembaga agama dan faktor emosional.

\section{SIMPULAN DAN SARAN}

\section{Simpulan}

Sikap remaja dikabupaten boyolali terhadap HIV/AIDS sesuai tingkat pengetahuannya tentang HIV/AIDS. Pada remaja yang tingkat pengetahuan tentng HIV/AIDS baik sikapnya terhadap HIV/AIDS juga baik, pengetahuannya cukup sikapnya juga cukup begitu pula yang pengetahuanya rendah sikapnya terhadap HIV/AIDS juga rendah. Hasil penelitian ini menunjukkan ada hubungan antara pengetahuan dan sikap remaja tentang HID/AIDS di Kabupaten Boyolali.

\section{Saran}

Peningkatan pengetahuan tentang HIV/AIDS adalah hal yang sangat penting untuk perbaikan sikap terhadap HIV/AIDS. Pemberian pendidikan kesehatan/informasi adalah upaya utama peningkatan pengetahuan yang dapat dilakukan yang tentunya mengguanakan media yang paling banyak diakses responden, sesuai penelitian ini responden paling banyak memperoleh informasi tentang HIV/AIDS dari : televisi, sekolah, internet dan lain-lain. Dengan pengetahuan yang baik tentunya sikap untuk menghindari penularan dan upaya pencegahan akan dilakukan sehingga angka kejadian HIV/AIDS dapat di tekan. Dan sikap terhadap Orang Dengan HIV/AIDS (ODHA) juga tepat.

\section{DAFTAR PUSTAKA}

Arikunto S. .2002. Prosedur Penelitian Suatu Pendekatan Praktek. Rineka Cipta, Edisi Revisi V, Jakarta.

BBKBN. 2012. Survei Demografi dan Kesehatan Indonesia 2012 Kesehatan Reproduksi Remaja. http://kesga.kemkes.go.id/images/pedoman/SDKI2012-Remaja-Indonesia.pdf. Minggu 16 Des 18 jam 16.00 
Dinkes Kabupaten Boyolali. 2015. Profil Kesehatan Kabupaten Boyolali Tahun 2015 http://www.depkes.go.id/resources/download/profil/PROFIL_KAB_KOT A_2015/3309_Jateng_Kab_Boyolali_2015.pdf. $\quad$ Minggu 16 Desember2019.

Direktur Jendral P2M 2017. Laporan Perkembangan HIV/AIDS dan Penyakit Infeksi Menular Seksual (IMS) Triwulan IV Tahun 2017 (http://siha.depkes.go.id/portal/files_upload/Laporan_HIV_AIDS_TW_4_ Tahun_2017 1_.pdf hari minggu 16 Des 18

Gallant, J. 2010. 100 Tanya Jawab Mengenai HIV/ AIDS. Jakarta: Indeks.

Kusmiran, Eny. 2012. Kesehatan Remaja dan Wanita. Jakarta: Salemba Medika.

Lia. (2010). Hubungan Pengetahuan Suami Tentang HIV/AIDS dengan Pencegahan Berdasarkan Karakteristik di Desa Parakan Kauman Kecamatan Parakan Kabupaten Temanggung dalam

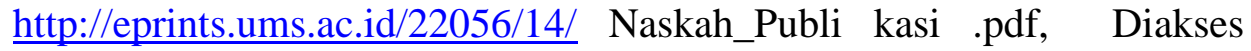
Tanggal 16 des 2018

Notoatmodjo S., 2002, Metodologi Penelitian Kesehatan, PT. Rineka Cipta, Jakarta.

Jakarta.

Nursalam, dkk. 2005. Asuhan Keperawatan Bayi dan Anak. Jakarta: Salemba Medika.

Sarwono, S, Meinarno, E. 2011. Psikologi Sosial. Jakarta : Salemba Humanika.

Wawan, A, Dewi, M. 2011. Teori dan Pengukuran Pengetahuan Sikap dan Perilaku Manusia.Yogyakarta : Nuha Medika.

Widyastuti, yani, dkk. 2009. Kesehatan Reproduksi. Yogyakarta: Fitramaya

World Health Organization. 2017. Kajian Nasional Respon HIV di Bidang Kesehatan RI. http://www.searo.who.int/indonesia/publications/hiv country_review_indonesia_bahasa.pdf jam 14.00 hari minggu 16 des 16 